(C) Тарарак Н. Г., 2019.

https://orcid.org/0000-0001-5350-8594

DOI: $10.34142 / 23128046.2019 .47 .11$

Н. Г. Тарарак

\title{
ВНЕСОК ВІТЧИЗНЯНИХ ПЕДАГОГІВ У РОЗРОБКУ ПИТАНЬ ПІДГОТОВКИ ВЧИТЕЛЯ-ВИХОВАТЕЛЯ
}

На сучасному етапі розвитку Украӥнської держави, етапі активної модернізаиії системи освіти, особливу увагу необхідно акиентувати на відродженні, відновленні всього педагогічно иінного, що вже було накопичено людством. 3 огляду на ие, у статті аналізується внесок вітчизняних педагогів (Феофан Вишенський, Іоанн Сергієв, Іван Успенський, Сергій Рачинський, Василь Зеньковський) у розробку питань підготовки вчителя до виховання молодого покоління.

Для розв'язання висунутої мети використано такі методи наукового пізнання, як: загальнонаукові (аналіз наукових джерел, синтез, узагальнення й систематизачія зібраного матеріалу), історичні (порівняльно-історичний, структурно-системний, ретроспективний, актуалізаціі) та хронологічні.

Аналіз творів Феофана Вишенського, Іоанна Сергієва (Кронштадтського), Івана Успенського, Сергія Рачинського, Василя Зеньковського дозволяе стверджувати, що зазначені педагоги приділяли велику увагу питанням підготовки вчителя-вихователя до організачії виховної діяльності з учнями. До провідних якостей, якими повинен володіти вчитель, педагоги відносили: наявність покликання, щэо виявлясться ще до вступу на вчительські спеціальності; сумлінність; справедливість; ретельну підготовка до кожного уроку; постійне самовдосконалення; наявність наукових знань, котрі необхідні для здійснення професійної діяльності; постійне вдосконалення кожного уроку; турботу про те, щоб урок був більш цікавим, зрозумілим і доступним для засвоєння; любов до дітей, яка не закінчується навіть тоді, коли учні платять невдячністю, не цінують доброго ставлення до себе з боку вчителя $i$ зловживають його любов'ю та ін.

3'ясовано, щзо проаналізовані твори зазначених авторів стосовно підготовки вчителя до організації виховної діяльності підростаючого покоління, відзначаються співзвучністю педагогічних ідей минулих років із сучасністю, а саме: розвиток дитини повинен відповідати ї̈ фізичним та духовним можливостям, природним здібностям; виховання дитини не можна пов'язувати з ї фізичним та моральним насильством; виховання - це багатоаспектний процес, який здійснюється вихователями, вчителями, батьками та ін.; процес виховання повинен здійснюватися людьми, спеціально підготовленими. 
Ключові слова: вчитель-вихователь, підготовка, виховання, молоде покоління.

Tararak N. H. Contribution of native pedagogues to the development of issues of form teachers training. At the present stage of the development of the Ukrainian state, which is the stage of active modernization of the education system, special attention should be paid to the revival, restoration of everything pedagogically valuable that has already been accumulated by mankind. In view of this, the article analyzes the contribution of native pedagogues (Feofan Vyshenskyi, Ioann Serhiiev, Ivan Uspenskyi, Serhii Rachynskyi, Vasyl Zenkovskyi) to the development of issues of teacher preparation for the upbringing of the younger generation.

To reach the goal, the following methods of scientific cognition were used: general scientific (analysis of scientific sources, synthesis, generalization and systematization of collected material), historical (comparative and historical, structural and systematic, retrospective, actualization) and chronological updates.

The analysis of the works of Feofan Vyshenskyi, Ioann Serhiiev (Kronshtadtskyi), Ivan Uspenskyi, Serhii Rachynskyi, Vasil Zenkovskyi suggests that these teachers paid great attention to the issues of preparing the form teacher to the organization of educational activities with students. According to the pedagogues, the leading qualities that a teacher should have include: the presence of a vocation, which is manifested even before joining the teaching specialties by students; honesty; justice; thorough preparation for every lesson; constant selfimprovement; availability of scientific knowledge necessary for the professional activity; continuous improvement of every next lesson; trying to make lessons more engaging, understandable and accessible; love for children, which does not end even when the students are ungrateful, do not appreciate the good attitude and abuse the teacher's love, etc.

It has been found that the analyzed works regarding the preparation of the teacher for organizing the educational activity of the younger generation are notable for the harmony of pedagogical ideas of past years with the present, namely: the development of a child should correspond to his or her physical and spiritual abilities, natural abilities; the upbringing of a child cannot be linked with his or her physical and moral abuse; upbringing is a multidimensional process carried out by educators, teachers, parents, etc.; the education process should be carried out by specially trained people.

Keywords: teacher, training, education, young generation.

Вступ. На сучасному етапі розвитку Української держави, етапі активної модернізації системи освіти, особливу увагу необхідно акцентувати на відродженні, відновленні всього педагогічно цінного, що вже було накопичено людством. Ці положення знайшли своє відбиття в Конституції України (1996р.), Концепції громадянського виховання особистості в умовах 
розвитку української державності (2000р.), Стратегії національнопатріотичного виховання дітей та молоді на 2016-2020 роки (2015 р.), Законах України «Про освіту» (1991р.), Національній стратегії розвитку освіти в Україні на період до 2021 року (2013 р.) та деяких інших документах. Особлива увага в зазначених законах та концепціях приділяється питанням підготовки вчителя до виховання молодого покоління.

Спектр досліджень, які можуть слугувати основою для розв’язання окресленою проблеми є досить широким. Вивчення та узагальнення науковопедагогічних джерел дозволяє стверджувати, що останнім часом 3'явилися праці, в яких всебічно аналізуються погляди видатних вітчизняних та зарубіжних педагогів, психологів, філософів щодо змісту, форм та методів виховання особистості (С. Білецька, А. Відченко, В. Ворожбіт-Горбатюк, С. Золотухіна та ін.); обгрунтовуються питання виховання особистості в умовах сім’ї (Т. Алексєєнко, В. Постовий, В. Шинкаренко та ін.); аналізуються особливості підготовки вчителя до організації виховної діяльності на різних етапах розвитку українського суспільства (В. Вихрущ, В. Вербець, Л. Данилова, Н. Дем'яненко, О. Попова та ін.).

Мета та завдання. Мета статті полягає у визначенні внеску вітчизняних педагогів (Феофан Вишенський, Іоанн Сергієв, Іван Успенський, Сергій Рачинський, Василь Зеньковський) у розробку питань підготовки вчителя до виховання молодого покоління.

Методи дослідження. Для розв'язання висунутої мети використовувалися такі методи наукового пізнання, як: загальнонаукові (аналіз наукових джерел, синтез, узагальнення й систематизація зібраного матеріалу), історичні (порівняльно-історичний, структурно-системний, ретроспективний, актуалізації) та хронологічні.

Результати. Вивчення та узагальнення науково-педагогічних джерел свідчить про те, що до вітчизняних фахівців, які зробили суттєвий внесок у розробку питань, що вивчаються, можна віднести Феофана Вишенського (1815 - 1884 рр.), Іоанна Сергієва (Кронштадтського) (1829 - 1908 рр.), Івана Успенського (1872 - 1937 рр.), Сергія Рачинського (1833 - 1902 рр.), Василя Зеньковського (1881 - 1962 рр.).

Так, Феофан Вишенський склав своєрідний посібник для вчителів «Листи про християнське життя». У зазначеній праці дослідник пов'язав процес виховання особистості з психологією і обгрунтував цілу науку про виховання, яку вважав «найсвятішою з усіх святих справ» (Feofan,1899).

Для вдосконалення процесу виховання молодого покоління фахівець пропонував: організацію виховання у родині, оскільки сімейне виховання $\epsilon$ фундаментом усього наступного; внесення християнських елементів у 
шкільне виховання; ретельну підготовку самих вихователів до організації виховного процесу.

3 віком, наголошував педагог, необхідно розвивати всі сили дитячої душі: розум, волю і серце, а також навчитися спостерігати за розвитком дитячої особистості.

Виховання, зазначав Феофан Вишенський, повинно бути таким, щоб не руйнувало те, що закладено в дитинстві. Найбільш складним для виховання особистості науковець уважав юнацький вік, який розглядав як «нестійкий i мінливий період людського життя».

Педагог уважав корисною тільки таку освіту, яка розвиває розум та ушляхетнює серце. На думку науковця, кожна школа має базуватися на принципах моральності. Спочатку необхідно сформувати у свідомості та серці школяра основні моральні істини, а потім уже будувати наукову систему освіти (Smirnov, 1899; Feofan, 1897).

Феофан Вишенський постійно спростував твердження тих фахівців, які вважали розвиток природи людини цілком достатнім. Свою точку зору фахівець обгрунтовував таким чином:

- необхідно вихованців постійно привчати до мистецтв та витончених речей шляхом розвитку естетичного смаку;

- дбати про те, щоб привчати вихованців триматися гідно, навчати їх гарним манерам;

- постійно привчати вихованців до різноманітної творчої діяльності (Feofan, 1895).

Феофан Вишенський також сформулював виховну мету закладів освіти, яка спрямована на «просвітлення розуму та освіченість серця». Такий шлях науковець уважав єдиним правильним. Зазначений шлях, на думку фахівця, забезпечував не тільки залучення розуму школярів до високих цінностей життя, а й сприяв особистісному сприйняттю цих цінностей внутрішнім світом дитини, організації іiі життедіяльності.

Для забезпечення успіху у вихованні молодого покоління науковець уважав, що кожному вчителю необхідно позбавитись таких недоліків, як:

- жалість до себе;

- надмірна залежність від матеріальних речей і задоволень;

- догоджання людям;

- надмірна «прив’язаність» до земного життя (Smirnov, 1915).

Ідеї, співзвучні педагогічним поглядам Феофана Вишенського, мають місце у працях Іоанна Сергієва (Кронштадтського), який понад тридцяти років працював у Кронштадтському повітовому училищі та гімназії (Ioann Sergiev, 1990). 
За глибоким переконанням I. Сергієва, для успішної організації виховного процесу в закладах освіти необхідно також, щоб педагогвихователь відповідав своєму статусу і щоб виховання було церковним. Іоанн Сергієв слушно наголошував на тому, що необхідно виховувати не лише корисних членів суспільства, але і надзвичайно добрих людей.

Успіх Іоанна Сергієва, як викладача, забезпечувався його незвичайною особистістю і розумінням свого призначення як педагога. Як викладач, він добре умів запалювати «духовний вогник» у своїх учнів. Його можна вважати взірцем для кожного практикуючого i потенційного вчителявихователя. Також I. Сергієв постійно наголошував на необхідності грунтовної підготовки викладачів до уроків та організації виховної діяльності з учнями. «Чи учиш своїх дітей, чи чужих, - зазначав педагог, - перетворюй справу в служіння Богові, учачи їх із завзятістю, заздалегідь обдумуючи засоби до научання - ясного, зрозумілого, повного і плідного» (Otec Ioann Kronshtadtskij, 1909).

До провідних прийомів виховання особистості, які застосовував і сам у своїй практичній педагогічній діяльності, І. Сергієв відносив: відсутність покарань; опитування насамперед учнів, що готові відповідати; переказ Святого Письма.

Педагог дуже любив маленьких дітей і до них ставився 3 особливою повагою. 3 цього приводу він писав: «Я серед дітей і себе дитиною відчуваю». І. Сергієв із задоволенням відвідував училища, дитячі притулки, гімназії (Otec Ioann Kronshtadtskij, 1909).

Вагомий внесок у справу виховання молодого покоління та підготовки вчителя до виховної діяльності зробив відомий педагог ХІХ століття - Іван Успенський, який тривалий час викладав у семінарії та на вчительських педагогічних курсах. Результатом плідної педагогічної діяльності стала його праця «Записки з дидактики» (1902р.), у якій дослідник виклав свої погляди на педагогічну науку. Основне своє призначення I. Успенський бачив у тому, щоб надати допомогу вчителям щодо правильного розуміння існуючих теорій і поглядів на освіту та виховання, навчити їх свідомо виконувати свою справу.

Під виховним процесом педагог розумів усебічний розвиток сил дитини. Виходячи 3 конкретних цілей, І. Успенський говорив про різні види виховання - фізичне (метою якого є зміцнення тіла та здоров'я вихованця), духовне (передбачає розвиток розумових сил учня) (Faddej, 1902).

Педагог також сформулював і завдання, які стоять перед школою i вчителем. Зокрема, І. Успенський наголошував на тому, що діяльність учителя-вихователя не повинна обмежуватися читанням, письмом, 
рахуванням, тобто тільки турботою про розвиток розуму. Необхідно більше уваги приділяти вихованню у дітей душевних якостей. Педагог справедливо вважав, що без виховання не може бути організоване успішне навчання.

Він також наголошував на тому, що завдання школи і вчителя полягає у привчанні дітей до уважності, зосередженості, бо дитина живе більше серцем, ніж розумом (Faddej, 1902).

За глибоким переконанням І. Успенського, правильним і відповідним природі людини є лише християнське виховання: «Тільки християнство вказує для виховання мету найбільш правильну, високу і відповідну природі людини» (Faddej, 1902).

Вивчення праць педагога свідчить про те, що він висував достатньо високі вимоги до особистості вчителя-вихователя, до його моральних якостей, бо справедливо вважав, що для того, щоб успішно впливати на душу вихованця, вчитель сам повинен мати ті якості, котрі хоче виховати у своїх учнів.

На нашу думку, цінними є вимоги І. Успенського до вчителя та його особистісних якостей, а саме: наявність покликання, що виявляється ще до вступу на вчительські спеціальності; сумлінність; справедливість; ретельна підготовка до кожного уроку; постійне самовдосконалення; наявність наукових знань, котрі необхідні для здійснення професійної діяльності; постійне вдосконалення кожного уроку; турбота про те, щоб урок був більш цікавим, зрозумілим і доступним для засвоєння; любов до дітей, яка не закінчується навіть тоді, коли учні платять невдячністю, не цінують доброго ставлення до себе з боку вчителя і зловживають його любов'ю.

За твердим переконанням педагога, терпіння і справедливість - це ті головні якості вчителя-вихователя, що роблять його характер міцним i послідовним у всьому. Також І. Успенський рекомендував практикуючим i потенційним учителям якомога частіше звертатися до педагогічної літератури, до творів педагогів та психологів (Faddej, 1902).

Зокрема, педагог визначив коло читання вчителя. Він справедливо вважав, що людина, яка вирішила присвятити себе вчительській діяльності, повинна читати твори з педагогіки, дидактики, з окремих методик, а також знати історію педагогіки, цікавитися науками, котрі безпосередньо вивчають питання виховання і навчання особистості. І. Успенський рекомендував майбутнім учителям звертатися до праць О. Анастасієва, Я. Коменського, К. Ушинського, Ж.-Ж. Руссо, С. Миропольського, П. Каптерєва, барона Корфа, К. Побєдоносцева, Л. Толстого, Й. Песталоцці та ін.

Педагог також слушно наголошував на важливості психології у вивченні законів розвитку душевного життя особистості (Faddej, 1902). 
Педагогічну цінність мають i думки освітянина про те, що запропоновані вчителем прийоми викладання повинні відповідати віку школярів, особливостям дитячої психіки. Вчитель повинен бути спостережливим, уміти «опускатися» до дитячих поглядів і почуттів, ставити себе на місце дитини (Faddej, 1902).

На думку І. Успенського, потрібно, щоб учень самостійно, усвідомлено, 3 розумінням засвоював отримані знання, умів знайти необхідні знання та використовувати їх на практиці.

Педагог надавав переваги використанню в навчальному процесі двох основних дидактичних форм - описово-розповідної i запитальновідповідальної. Запитально-відповідальну форму він поділяв на два види: катехізисну, коли відповіді дає учитель або учень на підставі вже отриманих знань; евристичну, коли вчитель підштовхує дітей доходити до всього шляхом запитань-підказок самостійно (Faddej, 1902).

Також I. Успенський особливе виховне значення приділяв дисципліні, яка, за його думкою, сприяє зміцненню волі, вихованню покори, терпіння, стриманості та викоріненню свавілля, привчає школярів до думки, що вони мають робити в класі тільки те, чого вимагає загальна користь.

Великого значення педагог надавав методам заохочення, використанню нагород, які $є$ корисними для підтримки, схвалення учня і спонукають його до більш старанних занять і досконалої підготовки до уроку. Але, разом 3 тим, I. Успенський наголошував, що вчитель повинен обережно користуватися методом заохочення, так як нагородами можна легко виховати в дитини самолюбство і завищену самооцінку.

На думку педагога, слід також бути обережним і з методами покарання, які повинні повністю залежати від індивідуальних особливостей конкретного учня. Краще негативний вчинок з боку учня попередити, ніж за нього нести покарання.

Питаннями виховання особистості та підготовки вчителя до організації зазначеної діяльності займався і С. Рачинський, який багато уваги приділяв питанням морального та національного виховання дітей молодшого шкільного віку. «Справа народної школи, - наголошував педагог, - більш широка і більш глибока, ніж будь-яка громадська діяльність... Пора нам згадати, що в нас під ногами є спільний грунт, і твердо, і свідомо стати на нього. Пора усвідомити, що настав час взаємодії... Грунт цієї взаємодії, цього єднання - Церква; знаряддя його - школа i, переважно, школа сільська...» (Rachinskij, 1991).

Розробкою питань підготовки вчителя до виховання підростаючого покоління займався відомий вітчизняний педагог В. Зеньковський, життя та 
діяльність якого пов'язані з радянською добою. 3 цього приводу педагог писав: «Радянські педагоги вірять пристрасно в комунізм, живуть ним і не допускають жодної критики; ідея комуністичної реорганізації суспільства $\epsilon$ для них абсолютною істиною, про яку не дозволено навіть запитувати. 3 наївним і грубим фанатизмом вони «знімають» питання, сліпо вірячи у свою істину та шукаючи цілковитого розкриття лише ії... Радянська педагогіка, звичайно, є для них ancilla комуністичної теології, і в цій своєрідній релігійній установці їхньої творчості лежить пояснення багатьох рис радянської педагогіки» (Zen'kovskij, 2004).

Особливе значення для педагогіки має твердження В. Зеньковського про духовний вимір у людині: «Початок духовності мислиться нами не як особливе надпсихофізичне життя, а як основне життя в людині, провідниками якого зовні є психічна і фізична сфера. Тому в людині все особистісне, все цілісне і в своїй цілісності неповторне й абсолютно одиничне» (Zen'kovskij, 2004).

Внесок В. Зеньковського у педагогіку полягає і у визначенні ним сенсу людського життя, який зводиться до індивідуального та особистісного досягнення Абсолюту через реалізацію задуму Божого щодо неповторності життя кожної окремої людини.

С. Зеньковський до наукового обігу вводить поняття «цілісна особистість», яка об'єднує психічну, фізичну та соціальну складову життя людини (Zen'kovskij, 2004).

За переконанням педагога, людину необхідно виховувати у свободі, оскільки вона єдина наділена здатністю до вільного вибору та вільної дії. Виховання у свободі повинно включати виховання в істині та добрі. «Вона (свобода) потрібна душі як жива вода, що дає їй життя, дає ій крила», наголошував фахівець (Zen'kovskij, 2004).

Обговорення. Отже, проаналізовані нами твори зазначених авторів стосовно підготовки вчителя до організації виховної діяльності підростаючого покоління, відзначаються співзвучністю педагогічних ідей минулих років із сучасністю, а саме: розвиток дитини повинен відповідати іiі фізичним та духовним можливостям, природним здібностям; виховання дитини не можна пов'язувати з ії фізичним та моральним насильством; виховання - це багатоаспектний процес, який здійснюється вихователями, вчителями, батьками та ін.; процес виховання повинен здійснюватися людьми, спеціально підготовленими.

Висновки. Отже, аналіз творів Феофана Вишенського, Іоанна Сергієва (Кронштадтського), Івана Успенського, Сергія Рачинського, Василя Зеньковського дозволяє стверджувати, що зазначені педагоги 
приділяли велику увагу питанням підготовки вчителя-вихователя до організації виховної діяльності 3 учнями. До провідних якостей, якими повинен володіти вчитель, педагоги відносили: сумлінність; справедливість; постійне самовдосконалення; турботу про те, щоб урок був більш цікавим, зрозумілим і доступним для засвоєння; любов до дітей та ін.

\section{ЛІТЕРАТУРА:}

Зеньковский В. Педагогика. Клин : Фонд «Христианская жизнь», 2004. 202 с.

Иоанн Сергиев (Кронштадтский). Моя жизнь во Христе. Репр. изд. М., 1990. 125 с.

Отец Иоанн Кронштадтский. СПб. : Изд-во Рус. Нар. Союза им. Михаила Архангела, 1909. $153 \mathrm{c}$.

Рачинский С. Сельская школа. М. : Педагогика, 1991. 278 с.

Смирнов П. Жизнь и учение преосвященного Феофана, Вышенского Затворника. 2-е изд. М, 1915. $135 \mathrm{c}$.

Смирнов П. Народное образование и церковноприходская школа. СПб., 1899. 126 с.

Фаддей (иеромонах). Записки по дидактике. Уфа, 1902. 125 с.

Феофан (епископ). Начертание христианского нравоучения. 2-е изд. М. : Типолитогр. И. Ефимова, 1895. 519 с.

Феофан, еп. Письма о духовной жизни. 3-е изд. Афонского Русского Пантелеймонова монастыря. М. : Типолитография, 1897. 253 с.

Феофан, еп. Путь ко спасению: (краткий очерк аскетики) М. : Типолитогр. И. Ефимова, 1899. $346 \mathrm{c}$.

\section{REFERENCES:}

Zen'kovskij V. (2004). Pedagogika. [Pedagogy]. Klin : Fond «Hristianskaja zhizn'», 202 s. (in Russian).

Ioann Sergiev (Kronshtadtskij) (1990). Moja zhizn' vo Hriste. [My life is in christ]. Repr. Izd., 125 s. (in Russian).

Otec Ioann Kronshtadtskij. (1909). [Father John of Kronstadt]. SPb. : Izd-vo Rus. Nar. Sojuza im. Mihaila Arhangela, 153 s. (in Russian).

Rachinskij S. (1991). Sel'skaja shkola. [Rural School]. M. : Pedagogika, 278 s. (in Russian).

Smirnov P. (1915). Zhizn' i uchenie preosvjashhennogo Feofana, Vyshenskogo Zatvornika. [The life and teachings of Reverend Theophanes, the Vyshensky Recluse]. 2-e izd. M, 135 s. (in Russian).

Smirnov P. (1899). Narodnoe obrazovanie i cerkovnoprihodskaja shkola. [Public education and parish school]. SPb.,126 s. (in Russian).

Faddej (ieromonah). (1902). Zapiski po didaktike. [Notes on didactics]. Ufa, 125 s. (in Russian). Feofan (episkop). (1895) Nachertanie hristianskogo nravouchenija. [Inscription of Christian Morals]. 2-e izd. M. : Tipolitogr. I. Efimova, 519 s. (in Russian).

Feofan, ep. (1897). Pis'ma o duhovnoj zhizni. [Letters on spiritual life]. 3-e izd. Afonskogo Russkogo Pantelejmonova monastyrja. M. : Tipolitografija, 253 s. (in Russian).

Feofan, ep. (1899). Put' ko spaseniju: (kratkij ocherk asketiki) [The path to salvation: (a brief outline of asceticism)]. M. : Tipolitogr. I. Efimova, 346 s. (in Russian).

\section{Інформація про автора:}

Тарарак Наталія Григорівна:

ORCID: $\quad$ https://orcid.org/0000-0001-53508594, доктор педагогічних наук, професор, завідувач кафедри теорії $\mathrm{i}$ технології дошкільної освіти та мистецьких дисциплін,

\section{Information about the author:} Tararak NatalIya:

ORCID: https://orcid.org/0000-0001-53508594, Doctor of pedagogical sciences, Professor, Head of the Department of Theory and Technology of Preschool Education and 
Харківський національний педагогічний Arts, H. S. Skovoroda Kharkiv National університет імені Г. С. Сковороди, вул. Pedagogical University, Valentynivska street, Валентинівська, 2, м. Харків, Україна 61166 2, Kharkiv, Ukraine 61166

e-mail: dochfak_hnpu@mail.ru e-mail: dochfak_hnpu@mail.ru

Цитуйте цю статтю як: Тарарак Н. Г. Внесок вітчизняних педагогів у розробку питань підготовки вчителя-вихователя. Теорія та методика навчання та виховання. 2019. № 47. C. $123-132$.

DOI: $10.34142 / 23128046.2019 .47 .11$

Дата надходження статті до редакції: 19.11.2019

Стаття прийнята до друку: 02.12.2019 